\title{
Penetrating Missile Injuries in the Gulf War 1991
}

\author{
Surg Lt Cdr T J W Spalding \\ FRCS, RN*
}

Maj M P M Stewart

FRCS, RAMC

Surg Cdr D N Tulloch

FRCS, RN

\section{Col KM Stephens \\ FRCS, L/RAMC}

Department of Surgery, 32 Field Hospital, Saudi Arabia, BFPO 637

Originally published in the Br J Surg 1991; 78: 1102-1104 and reproduced by permission of the publishers Butterworth Heinemann Ltd.

SUMMARY: During the recent Gulf War 63 patients with penetrating missile injuries (including 29 Iraqi prisoners of war) underwent operation in a British Army Field Hospital. Their injuries and initial operative management are re ported. Fifty-one casualties (81\%) suffered an average of 9 wounds (range 1-45) due to fragmentation weapons, and 1\% casualties sustained bullet wounds. All wounds were explored following the established principles of war surgery. Th\& extremities were involved in 48 patients $(76 \%)$. Eight compound long bone fractures were managed with exter 7 at skeletal fixators applied at the time of initial operation. Laparotomy was performed on 7 patients, one of whom diffu응 The average duration of operation was 77 minutes for shrapnel wounds and 85 minutes for bullet wounds.

\section{Introduction}

The recent Gulf Conflict represented an unparalleled military success in the sphere of conventional warfare. The effectiveness of massive air bombardments and subsequent rapid armoured thrusts resulted in a short, sharp, one-sided offensive with unexpectedly few Allied wounded. It had been predicted that on a future conventional battlefield the effectiveness of modern explosive munitions would produce high mortality from high energy transfer wounds and blast injury, and that most casualties reaching hospital would have multiple low energy wounds caused by modern anti-personnel fragmentation devices (1-3).

The 32 Field Hospital was deployed as the most forward British surgical facility in support of the ground offensive. It handled both British casualties and Iraqi prisoners of war. We report on the initial operative procedures in 63 casualties and discuss specific aspects of their surgical management.

\section{Patients and Results}

\section{Field Hospital}

The hospital was established in its forward position on 20 January 1991. It comprised a reception/triage area, an 8 bay resuscitation department, a treatments area, an 8 table operating theatre, 8 surgical teams and 200 beds

*Now Nuffield Orthopaedic Centre, Windmill Road, Headington, Oxford $O X 37 L D$ in 4 wards. In addition a pathology laboratory an radiography facility were available.

Injured casualties received initial resuscitation a treatment at Regimental Aid Posts and Field Dres Stations. Following helicopter evacuation to 32 FFele Hospital, resuscitation was continued and appropriate radiographic studies were performed. Data on patient最 who underwent surgery were recorded on proformas t $\Theta$ include the date and time, cause and nature of injury $\vec{\sigma}$ duration of operation, operative findings and surgica management. Patients were evacuated on the first postoperative day to military general hospitals iR. southern Saudi Arabia.

\section{Presentation and Management of Injuries}

Between Jan 20 and Mar 6, 1053 patients were receive by the hospital and 100 operations were performed Sixty-three casualties sustained penetrating traum $\vec{z}$ because of missile injuries, 31 were British, 29 were Iraq prisoners of war and 3 were Egyptian. The causes of the missile injuries are outlined in Table 1 . Eighty per cent were due to fragments and three of 12 bullet wounds were high energy transfer injuries. Table 2 reflects the predominance of limb wounds in both fragment and bullet injuries $(76 \%)$, compared with chest wounds. $(12 \%)$ and abdominal wounds $(11 \%)$.

Fragmentation weapons inflicted multiple low energiv transfer wounds affecting more than one body area if $63 \%$ of cases (Table 3). One patient had sustaine 
Table 1

Causes of Missile Injuries. $(n=63)$

\begin{tabular}{llrl}
\hline Fragment & Not Specified & 40 & \\
& Mine & 5 & \\
& Grenade & 6 & \\
& & & $\overline{51}(80 \%)$
\end{tabular}

Bullet

$\begin{array}{ll}9 \mathrm{~mm} & 5 \\ 7.62 \mathrm{~mm} & 4 \\ 5.56 \mathrm{~mm} & 1 \\ \text { unknown } & 2\end{array}$

$12(20 \%)$

Table 2

Penetrating Missile Wounds: Site of Injury

\begin{tabular}{lrrrrrr}
\hline Site & \multicolumn{2}{c}{$\begin{array}{c}\text { Shrapnel } \\
(\mathbf{n}=\mathbf{5 1})\end{array}$} & \multicolumn{2}{c}{ Bullet } & \multicolumn{2}{c}{ Combined } \\
& No. & $\%$ & No. & \multicolumn{2}{c}{$\%$} & \multicolumn{2}{c}{ (n= } & No. & $\%$ \\
& 4 & 8 & 0 & 0 & 4 & 6 \\
\hline Head & 41 & 80 & 7 & 58 & 48 & 76 \\
Extremity & 24 & 47 & 4 & 33 & 28 & 44 \\
$\quad$ Upper Limb & 40 & 78 & 7 & 58 & 47 & 75 \\
$\quad$ Lower Limb & 8 & 16 & 0 & 0 & 8 & 12 \\
Chest & 6 & 12 & 1 & 8 & 7 & 11 \\
Abdomen & 16 & 31 & 1 & 8 & 17 & 26 \\
Buttocks & 4 & 8 & 0 & 0 & 4 & 6 \\
Back & & & & & &
\end{tabular}

Table 3

Shrapnel Wounds: No. of body areas involved $(n=51)$

\begin{tabular}{lrr}
\hline No. of areas & No. & $\%$ \\
\hline 1 & 19 & 37 \\
2 & 10 & 20 \\
3 & 10 & 20 \\
4 & 9 & 17 \\
5 or more & 3 & 6 \\
\hline
\end{tabular}

wounds to all four limbs, buttocks and back. The mean number of fragment wounds per patient was 9 (range 145).

The average time for a casualty to reach the hospital was $\mathbf{1 0 . 2}$ hours for Allied casualties and 24.7 hours for Iraqi POW's (Table 4). The mean duration of operation was 78.7 minutes; it was longer for bullet wounds ( 84.6 minutes) than for fragment injuries (77.3 minutes). These times include both the induction of anaesthesia and extubation, which were performed on the table.

Soft tissue wounds. Most fragment wounds affected soft tissue only (Table 5). All soft tissue wounds were explored according to established principles of war surgery (4). Wound edges were excised permitting free
Table 4

Mean Time for Allied and Iraqi patients to reach hos tal, operating theatre and duration of operation.

\begin{tabular}{|c|c|c|c|c|}
\hline & No. & $\begin{array}{c}\text { Time to } \\
\text { reach hospital } \\
\text { (hrs) }\end{array}$ & $\begin{array}{c}\text { Pre-operative } \\
\text { period } \\
\text { (hrs) }\end{array}$ & $\begin{array}{r}\text { Duration } 9 . \\
\text { operatiow } \\
\text { (mins) }\end{array}$ \\
\hline Allied Troops & 34 & 10.2 & 2.1 & $76.2 \stackrel{\bar{S}}{=}$ \\
\hline Iraqi POW's & 29 & 24.7 & 4.5 & $97.5^{\circ}$ 듣 \\
\hline
\end{tabular}

access to the damaged tissues beneath. Limb incisiogs were longitudinal, facilitating decompression of derlying muscle and visualisation of damaged structupes within the wound cavity. Viability of muscle was determined by colour, texture, contractility and lack . $\mathrm{f} f$ bleeding. All non viable muscle and fat was excised, antd foreign bodies that were easily accessible were remove

Wounds were irrigated with hydrogen peroxide a⿳⺈ dressed with dry gauze. Benzylpenicillin had been ministed to all casualties prior to arrival in hospital. Flucloxacillin was added to this regimen at operation and both were continued for a maximum of 5 days.

Bone Injury. Bone was fractured in 6 patients (50\% with bullet wounds and 17 patients $(33 \%)$ with fragment wounds. Following wound excision and lavage, toose avascular splinters of bone were removed, togetherawa $\mathrm{h}$ foreign bodies. External skeletal fixators ("Centrafixi, Military Pattern, Howmedica Ultra-X, New Jênsed, USA) were applied to 8 limbs at the initial operation $\vec{c}$ s follows: humerus-2, ulna-1, tibia- 4 and ankle and $B$ 1. All these fractures were either comminuted or asoci-

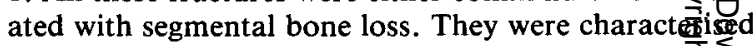
by severe soft tissue injury requiring extensive surgigal Table 5
Type of Injury and Type of Treatment for bullet
shrapnel wounds. $(n=63)$ Injury and Treatment Bullet Fragment Tota $(\mathbf{n}=12) \quad(\mathbf{n}=51) \quad(\mathrm{n}=\mathbf{6})$

\begin{tabular}{|c|c|c|c|c|c|}
\hline Soft Tissue & 6 & & 51 & & $57(85$ 要 \\
\hline Wound excision & & 6 & & 51 & \\
\hline Bone Injury & 6 & & 17 & & $23(3$ \\
\hline External Fixation & & 3 & & 5 & \\
\hline Amputation & & $\mathbf{0}$ & & 4 & \\
\hline POP Splintage & & 3 & & 8 & \\
\hline
\end{tabular}

Thoracic Injury

Chest drain

0

Abdominal Injury Laparotomy

Vascular Injury

Vein Patch

Lateral Suture

$$
\text { (2) }
$$


Table 6

Management of Abdominal Injuries.

\begin{tabular}{|c|c|c|}
\hline Patient & Laparotomy findings & Operative procedure \\
\hline 1 & $\begin{array}{l}\text { Penetration of liver and } \\
\text { common bile duct }\end{array}$ & $\begin{array}{l}\text { T-tube drainage CBD } \\
\text { Drainage Liver }\end{array}$ \\
\hline 2 & Penetration of liver & No procedure \\
\hline $3^{*}$ & $\begin{array}{l}\text { Penetration of liver, } \\
\text { spleen and rectum }\end{array}$ & $\begin{array}{l}\text { Splenectomy, Hartmann's } \\
\text { procedure }\end{array}$ \\
\hline 4 & Penetration of Stomach & Two-layer closure \\
\hline 5 & Negative Laparotomy & - \\
\hline 6 & Penetration of Liver & No procedure \\
\hline \multirow[t]{2}{*}{$7 * *$} & $\begin{array}{l}\text { Penetration of Rectum, } \\
\text { Ileum and caecum }\end{array}$ & $\begin{array}{l}\text { Right hemicolectomy, } \\
\text { ileostomy, mucus fistula and } \\
\text { Hartmann's procedure }\end{array}$ \\
\hline & $*$ = Died & $* *=\mathrm{GSW}$ \\
\hline
\end{tabular}

excision and wide fasciotomy. When applying the fixators, simple, unilateral, single plane configurations were constructed. Pin tracks were pre-drilled and pins introduced by hand through generous skin and fascia releasing incisions. When bone mass was lost the fracture was held distracted to preserve limb length and axial alignment. Restoration of continuity was not practised in tendon and nerve injury.

Three patients underwent completion of traumatic amputations (bilateral through knee, Symes, and mid forearm). POP splintage was applied in 11 hand and foot injuries.

Abdominal Injury. Six patients with fragment wounds and 1 patient with a bullet wound received injuries to the abdomen necessitating laparotomy (Table 6). Fragment wounds to the liver did not cause significant bleeding, and no further procedure was required. Case 3 was the only fatality having sustained multiple fragment wounds to both lower limbs, buttocks and abdomen, with perforation of the liver, spleen and rectum.

Thoracic Injury. Thoracic penetration resulted in haemopneumothorax in 5 patients with multiple fragment injuries. All were managed with local wound excision and chest drainage without the necessity for thoracotomy.

Vascular Injury. Vascular injury was rare: one fragment wound to the brachial artery was reconstructed using a vein patch graft and a bullet wound to the profunda femoris artery was repaired using a lateral suture technique.

\section{Discussion}

Despite the potential magnitude of the Gulf Conflict, Allied casualty figures were low. The pattern of wounding seen in this small series was in keeping with experience from previous conventional battles $(1,4,5)$. Fragment wounds accounted for $81 \%$ of casualties and were caused by modern anti-personnel weapons. An a erage of 9 low energy transfer wounds were inflicted per patient. This emphasises the inherent design features the modern preformed fragment device, designed largety to incapacitate rather than kill.

The average operating time of 77 minutes illustrates the burden that the treatment of non life-threatenir fragment injured casualties can impose upon surgicgl resources during war. When faced with the circurs stances of multiple wounds in multiple patients the surgeon may be tempted to adopt less aggressive surgic management $(6,7)$. Our experience of battlefield injuriess included many malnourished casualties, with multiple fragment wounds which were typically heavily contan $\overrightarrow{0}$ inated and more than 24 hours old. At operation, the extent of the cavity and degree of tissue necrosis beneags the small puncture fragment wounds illustrated that even at moderate range, these fragments generate suf ficient energy transfer to form a temporary cavity, which results in skin and fibres of clothing being dispersed $\overrightarrow{\mathbf{m}}$ radial fashion within the wound. These findings rein force the military dictum that all penetrating missike wounds should be thoroughly explored and that ore should err on the side of a more radical excision $(7,9)$. (f) the 63 casualties 48 patients $(76 \%)$ sustained limb wounds in this series. Missile fractures were seen in 29 these 48 patients $(48 \%)$ but only eight $(17 \%)$ involye long bones and required external fixation. In the last decades external skeletal fixation has undergone pre naissance in the management of severe limb wound \$as sociated with fractures in war $(10,11)$. This fact has teet due in large part to improvements in design and the $\mathrm{d} g$ velopment of basic principles which govern their sace and effective application (12). Experience in rece conflicts has emphasised that an ample supply of figsators is essential in war and that military surgeons shougl be trained in their use (11). The external fixators used our 8 cases were simple, versatile and disposable systen specifically designed for use by surgeons in field hospi tals.

Coupland has suggested that application of an external fixator has lower priority than wound excisio and should be delayed until delayed wound closure ( 1 情. We found external fixators applied at the time of initiol surgery provided immediate stabilisation of soft tissues, and assured limb length and axial alignment when bowe mass was lost. Additional benefits included the redue tion of patient discomfort during rearward evacuation to a general hospital.

Allied and Iraqi casualties showed a pattern of penetrating injury in keeping with a perceived conver tional battlefield. This series has underlined the fectiveness of present day anti-personnel munitions and highlighted the continued requirement, in the practice military surgery, for a clear understanding of the mecks anism of wounding in war and the appropriate manages ment. 


\section{Acknowledgements}

We would like to thank Colonel I McCahon (Head of Department), Squadron Leaders G Howell, P Schranz, and $A$ Weatherall for permission to report on their cases. We would like to thank Surgeon Commander R F Dale for the many hours spent preparing the proformas and computer program.

\section{REFERENCES}

1. Ryan J M, Cooper G J, Haywood I R, Milner S M. Field Surgery on a Conventional Battlefield: Strategy and Wound Management. Ann R Coll Surg Engl 1991; 73: 13-20.

2. Ryan J M, Cooper G J, Maynard R L. Wound ballistics: contemporary and future research. $J R$ Army Med Corps 1988; 134: 119-25.

3. CoOper G J, RyAN J M. The interaction of penetrating missiles with tissues - some common misapprehensions, and the implications for wound management. Br J Surg 1990; 77: 606-610.

4. Kirby N G, Blackburn G, eds. Field Surgery Pocket Book. London: HMSO, 1983.

5. Jackson D S, Batty C G, Ryan J M, MCGregor W $S$ P. The Falklands War: Army Field Surgical Experience. Ann R Coll Surg Engl 1983; 65: 281-285.

6. Broome G, Butler-Manuel A, Budd J, Carter P G. The Hungerford shooting incident. Injury 1988; 19: 313-317.

7. Marcus N A, Blair W F, Shuk J M et al. Low velocity gun shot wounds to extremities. $J$ Trauma 1961; 1: 354-360.
8. Coull J T. Military Surgery. Injury1990; 21: 2 通 272.

9 Rautio J, PaAvolainen P. Afghan war wounded: experience with 200 cases. $J$ Trauma 1988; 28: 523 5.

10. Zinman C, Reis N D. External Fixation in Wartirge limb surgery. Israel JMed Sci 1984; 20: 308-310.

11. Trouwborst A, Weber B K, Dufour D. Mediga Statistics of Battlefield casualties. Injury 1987; 18: 96-99.

12. Behrens F, Searls K. External Fixation of the tibia. Basic concepts and prospective evaluation Bone Joint Surg (Br) 1986; 68B: 246-254.

13. Coupland R M. Technical aspects of war wougd excision. Br J Surg 1989; 76: 663-667.

Penetrating Missile Injuries in the Gulf War 1991

The paper by Surg Lt Cdr Spalding and authors on page 129 was originally published in British Journal of Surgery 1991; 78: 1102-1104 a gुd is reproduced by permission of the publishers Butterworth Heinemann Ltd.

Double reporting of data is deprecated by most medical Journals including this Journal. However in this case it was felt that the paper deserved thie attention of the RAMC readership and is reproduced at the request of the Professor of Milfipary Surgery.

Any future quotation of this paper should refer its original appearance in the British Journ $₫$ \&f Surgery. 